\title{
Control of Tobacco Bacterial Wilt by an Avirulent Strain of Pseudomonas solanacearum M4S and Its Bacteriophage
}

\author{
Hiroshi TANAKA*, Hideaki Negishi* and Hatsue MaEdA**
}

Key words: biological control, Pseudomonas solanacearum, tobacco, bacterial wilt.

Treatments with heat-killed cells of Pseudomonas solanacearum ${ }^{1)}$, a living avirulent strain of $P$. solanacearum $\mathrm{M}^{4} \mathrm{~S}^{2)}$ or avirulent bacteriocin-producing strains of $P$. solanacearum ${ }^{3,4)}$ have been used in attempts to control bacterial wilt of tobacco, caused by $P$. solanacearum. Similarly, avirulent, non-bacteriocin-producing strains of $P$. solanacearum have been tested for controlling brown rot of potato, caused by the same pathogen ${ }^{5)}$. Although tobacco plants were protected with treatment of $\mathrm{M}_{4} \mathrm{~S}^{2}$, its efficacy was not sufficiently high for commercial use.

Although bacteriophages in $P$. solanacearum have been previously described ${ }^{6)}$, they have not been used as a means to control bacterial wilt of tobacco. The possibility of disease control using bacteriophage alone or in combination with other control measures was examined in this study.

Seeds of Japanese domestic tobacco cultivar 'Shiroenshu 1' were sowed in a greenhouse seedling bed. Six weeks after sowing, seedlings were transplanted to clay pots $12 \mathrm{~cm}$ in diameter and maintained at $28 \mathrm{C}$ in the greenhouse.

Virulent strains of $P$. solanacearum used in this study were U-10 and U-166, both were isolated from diseased tobacco in Oyama City in Tochigi Prefecture and Ohmiya Town in Ibaraki Prefecture in Japan, respectively. An avirulent strain of $P$. solanacearum $\mathrm{M} 4 \mathrm{~S}^{2)}$, described previously, was also used. The bacteria were grown on Kelman's TZC medium ${ }^{7)}$ at $28 \mathrm{C}$ and maintained at room temperature in sterilized distilled water.

The phage was isolated from the stems of diseased tobacco as follows: ten grams of stems were cut into small pieces (each side approximately one $\mathrm{cm}$ ) and shaken in $100 \mathrm{ml}$ of sterilized water in an Erlenmyer flask. Ten $\mathrm{ml}$ of filter sterilized extracts were added to $100 \mathrm{ml}$ of CPG broth $^{7)}$ inoculated with the host bacterium. After shake-culturing on a rotary shaker (150 $\mathrm{rpm}$ ) at $28 \mathrm{C}$ for 2 days, the culture was centrifuged at $10,000 \mathrm{rpm}$ for $20 \mathrm{~min}$. Phages were detected and isolated by plaque formation on a lawn of $P$. solanacearum U-10. The phage designated P4282 was purified by isolating single plaques three times. It was stored at $5 \mathrm{C}$ in CPG broth from shake-cultures of $P$. solanacearum M4S, removing host cells via $0.22 \mu \mathrm{m}$ membrane filtration.

A culture of M4S was grown in CPG broth in a jar-fermenter. Cells were harvested by centrifugation and stored in a freezer at $-20 \mathrm{C}$ until use. The cells were thawed by the addi-

* Japan Tobacco Inc., Applied Plant Research Laboratory, Yokohama Center, 6-2 Umegaoka, Midori-ku, Yokohama 227, Japan日本たばこ産業 (株) 植物開発研究所横浜センター

** Japan Tobacco Inc., Applied Plant Research Laboratory, 1900 Idei, Oyama, Tochigi 323, Japan 日本たばこ産業 (侏) 植物開発研究所

1) Tanaka, H. (1983). Ann. Phytopath. Soc. Japan 49: 66-68. 2) Tanaka, H. (1985). Bull. Utsunomiya Tob. Expt. Sta. 21: 1-66 (in Japanese). 3) Chen, W.Y. and Echandi, E. (1984). Plant Pathology 33: 245-253. 4) Chen, W., Echandi, E. and Spurr, H.W., Jr. (1981). In Proc. Fifth International Conference on Plant Pathogenic Bacteria. pp. 482-492. 5) Kemp, J. and Sequeira, L. (1983). Plant Disease 67: 499-503. 6) Matsumoto, T. and Okabe, N. (1935). J. Plant Protec. 22: 15-20 (in Japanese). 7) Kelman, A. (1954). Phytopathology 44: 693-695. 
tion of sterilized distilled water, stirred on a magnetic stirrer at room temperature and adjurted to $10^{8} \mathrm{cfu} / \mathrm{ml}$ at use. Virulent bacterial strains were grown on TZC agar medium at $28 \mathrm{C}$ for 2 days and the cells were transferred to sterilized distilled water. The concentration of virulent cells was adjusted to $10^{7} \mathrm{cfu} / \mathrm{ml}$. P. solanacearum M4S mixed with the phage was grown in CPG broth on a rotary shaker $(120 \mathrm{rpm})$ at $28 \mathrm{C}$ for 2 days. Bacterial cells were removed by centrifugation followed by membrane filtration. The broth was diluted 100 times with sterilized distilled water $\left(10^{7}\right.$ plaque forming units $\left./ \mathrm{ml}\right)$. In some experiments, phage particles were partially purified by precipitation with polyethylene glycol (PEG 6000) following the method of Maniates et al. $^{8}$ )

Culture filtrate was used as a sample for electron microscopic observation. The sample was negatively stained with $2 \%$ uranylacetate on carbon-coated collodion film. The specimen was examined in a JEM-100B (JEOL) electron microscope at $80 \mathrm{kV}$.

The phage P4282 in culture filtrate had a polygonal head $(c a .69 \mathrm{~nm})$ and a short tail $(c a$. $20 \mathrm{~nm}$ ) (Fig. 1), the same shape as Psso 154 and Psso NCL reported by Hendrick and Sequeira9). P4282 lysed both U-10 and M4S but not U-166.

For pre-inoculation with avirulent strain M4S, roots of tobacco plants were placed in the bacterial suspension for one hour before transplanting to pots. Immediately after transplanting, $100 \mathrm{ml}$ of diluted culture filtrate containing phage (CF) was poured into the pot.

Four days after transplanting, plants were inoculated with virulent $P$. solanacearum. Ten $\mathrm{ml}$ of bacterial suspension was applied to roots injured prior to inoculation by insertion of a knife.

Disease incidences were recorded 2 weeks after inoculation with virulent $P$. solanacearum using the following index: $0=$ no symptoms, $1=$ up to $25 \%$ of the foliage wilted, $2=25-50 \%$ of the foliage wilted, $3=50-75 \%$ of the foliage wilted, $4=75-100 \%$ of the foliage wilted, and $5=$ dead.

Tobacco plants were protected from wilting by pre-treatment with M4S and subsequent treatment with CF (Table 1). Pre-inoculation with M4S alone showed significantly lower incidence and severity of wilt, compared to the untreated control. Treatment with both M4S and CF was more efficacious than either treatment alone in decreasing wilting. There were no significant differences in efficacy among the CF treatments applied at different times after inoculation with M4S.

Tobacco plants were significantly protected by treatment with a combination of M4S and

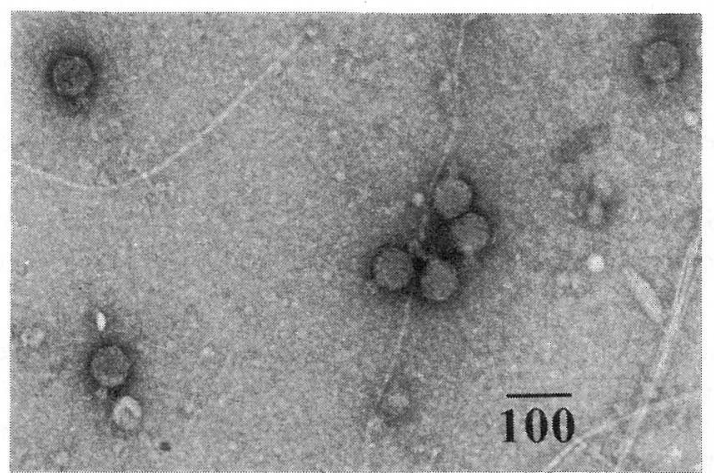

Fig. 1. Electron micrograph of bacteriophage of P. solanacearum, P4282. Bar, $100 \mathrm{~nm}$.

8) Maniates, T., Fritsch, E.F. and Sambrook, J. (1982). Molecular Cloning: a Laboratory Manual. Cold Spring Harbor Laboratory. Cold Spring Harbor, New York. 9) Hendrick, C.A. and Sequeira, L. (1984). Appl. Environ. Microbiol. 48: 94-101. 
$\mathrm{CF}$, prior to challenge with virulent strain U-10, susceptible to the phage. In the case of virulent strain U-166, tolerant to the phage, the effects of M4S and CF were greatly diminished (Table 2).

There was no difference in severity or incidence of wilt, when tobacco plants were pre-treated with M4S and subsequently treated with CF or partially purified phages (Table 3 ).

Cross sections of stems $(\mathrm{ca} .1 \mathrm{~cm}$ in thickness) were crushed in sterilized distilled water. Presence of M4S was determined by culture on $P$. solanacearum selective medium ${ }^{10}$. The presence of phages were examined by plaque formation on double layered plates using M4S as an indicator. Among 20 plants pre-treated with both M4S and CF, the phage was recovered from 9 of the 18 plants from which M4S was recovered (data not shown).

Table 1. Protection of tobacco plants from bacterial wilt by avirulent Pseudomonas solanacearum M4S and culture filtrate containing bacteriophage (CF)

\begin{tabular}{|c|c|c|c|c|}
\hline \multicolumn{3}{|c|}{ Treatment a) } & \multirow[b]{2}{*}{$\%$ Wilted plant } & \multirow[b]{2}{*}{ Disease index $b$ ) } \\
\hline $\begin{array}{c}\text { M4S } \\
\text { (Primary) }\end{array}$ & $\begin{array}{c}\mathrm{CF} \\
\text { (Secondary) }\end{array}$ & Interval & & \\
\hline+ & + & $1 \mathrm{hr}$ & $17.6 \mathrm{Ac}^{\mathrm{c}}$ & $0.58 \mathrm{AB}$ \\
\hline+ & + & 3 days & $14.1 \mathrm{~A}$ & $0.43 \mathrm{~A}$ \\
\hline+ & + & 5 days & $17.6 \mathrm{~A}$ & $0.53 \mathrm{AB}$ \\
\hline+ & + & 7 days & $14.5 \mathrm{~A}$ & $0.52 \mathrm{AB}$ \\
\hline+ & - & - & $39.5 \mathrm{~B}$ & 1. $26 \mathrm{~B}$ \\
\hline \multicolumn{3}{|c|}{ Untreated control } & $95.8 \mathrm{C}$ & 4. $06 \mathrm{C}$ \\
\hline
\end{tabular}

a) M4S : $P$. solanacearum M4S, CF: Culture filtrate containing bacteriophage.

$+:$ Treated, - : Untreated.

All plants were inoculated with $P$. solanacearum U-10 and experiments were repeated five times.

b) Disease index based on a scale from 0 (no visible symptoms) to 5 (dead).

c) Values followed by the same letter do not differ significantly at $P<0.05$ according to Duncan's multiple range test.

Table 2. Efficacy of M4S and phage treatment against the wilt diseases caused by phage-susceptible and phage-tolerant pathogenic $P$. solanacearum strains

\begin{tabular}{|c|c|c|c|}
\hline Treatment & $\begin{array}{c}\text { Inoculum } \\
\text { (Virulent strain) }\end{array}$ & $\%$ Wilted plant & Disease index \\
\hline M4S and CF & $\begin{array}{c}\text { U-10 } \\
\text { (Phage susceptible) }\end{array}$ & $7.5 * * * a)$ & $0.18 * * *$ \\
\hline Untreated control & U-10 & 87.5 & 4. 10 \\
\hline M4S and CF & $\begin{array}{c}\text { U-166 } \\
\text { (Phage tolerant) }\end{array}$ & $75.0 \mathrm{NS}$ & 3. $33 *$ \\
\hline Untreated control & U-166 & 95.0 & 4. 63 \\
\hline
\end{tabular}

a) $* * *, *$ : Statistically different by paired $t$-test, $P<0.001$ and 0.05 respectively, NS: Not significantly different by paired $t$-test. Experiments were repeated four times.

Table 3. Comparison of the efficacy of CF and partially purified phage

\begin{tabular}{ccc}
\hline \hline Treatment & $\%$ Wilted plant & Disease index \\
\hline M4S and CF & $11.7 \mathrm{a})$ & 0.22 \\
M4S and Phage & 5.0 & 0.06 \\
\hline
\end{tabular}

a) There is no significant difference between the treatments by paired $t$-test. Experiments were repeated six times.

10) Granada, G.A. and Sequeira, L. (1983). Plant Disease 67: 1084-1088. 
The results of this study indicate some enhancement of control of bacterial wilt of tobacco by $P$. solanacearum phage. Lack of involvement of bacteriocins or other kinds of antibacterial substances in culture filtrate was suggested for the following reasons (data not shown): (1) there was no in vitro antibacterial activity against U-10 or U-166 in culture filtrates of M4S devoid of the phage, (2) no protection of tobacco plants was afforded by the treatment with the phagefree M4S culture filtrate and (3) CF did not inhibit growth of U-166, tolerant to the phage, indicating antibacterial substances were absent in the CF preparation. Possible involvement of phage in protection of tobacco was suggested by: (1) degree of pathogen lysis was correlated to the degree of the protection (data not shown), (2) the protection was afforded by the treatment with the partially purified phage and (3) CF was not effective to U-166, phage tolerant strain.

Control of bacterial wilt of tobacco and brown rot of potato with avirulent strains of $P$. solanacearum has been reported on a greenhouse scale ${ }^{2-5}$ ) and also in a limited field trial ${ }^{2,4}$. However these control measures have not been reported for commercial production of these plants. Often single biological control measures are less efficacious than those afforded by conventional chemical control, and the use of avirulent strains of $P$. solanacearum is probably not an exception. Effective phage strains with wider host ranges, found by survey from nature or genetic manipulation, may offer an effective means for enhancing biological control of bacterial wilt.

We are grateful to Dr. Y. Takanami, Life Science Research Laboratory of Japan Tobacco Inc., for the electron micrograph of the bacteriophage. We are also grateful to Dr. R.V. Miller, Plant Pathologist of Mycogen Corporation, Ruston, Louisiana, USA, for reading and correcting the manuscript.

\section{和 文 摘 要}

田中 博・根岸秀明・前田初枝 : 非病原性タバコ立枯病菌Pseudomonas solanacearum M4S とバクテリオ ファージによるタバュ立枯病の生物防除

非病原性立枯病菌 M4S 菌の䯚濁液にタバコ苗を浸根, 鉢植えし, ファージを含む培養濾液 (CF) を添加, さらに病原性立枯病菌を接種した。 M4S 菌のみを前接種した場合，無処理にくらべて発病が抑制されたが， M4S 菌の前接種に加兄 CF を前処理した場合，さらに発病が抑制された。しかし，ファージが病原性菌に 感染しない場合には発病抑制勃果はみられなかった。CF 飞替えて部分精製したファージを用いた場合, CF 処理の場合との間に発病抑制効果に差は認められなかった。以上の結果から,ファージが発病抑制に関与す る可能性が示唆された。 